\title{
REGENERATION OF INORGANIC NUTRIENT IN EUTROPHIC ENVIRONMENT BY A BACTERIUM, XANTHOMONAS SP.
}

\author{
Md. Abdul Karim* and Rehena Nasrin Happy \\ Laboratory of Microbiology, Department of Botany, University of Dhaka, \\ Dhaka-1000, Bangladesh
}

Most water bodies in Bangladesh have been polluted due to industrial growth, urbanization. Increased amount of pollutants in water make it to become discolored, smelly and change the quality which may be dangerous to life. In extreme cases, large number of fishes may die. Sewage is a major household waste and it is one of the main sources of water pollution. It contains many organic constituents and microorganisms. They are potential hazards for the aquatic organisms and human beings. If they are allowed to mix with river and seawater without proper treatment, this may pose a threat for the living being of water and other consumers. Release of untreated wastewater into the near-shore environment for decades has the potential to degrade the environment (Biamon and Hajen 1983), infect indigenous species (Matches et al. 1974). From a microbiological perspective this has perhaps the most extensive impact on community structure, eutrophication and oxygen demand.

The river Buriganga is economically the very important to Dhaka city but it is threatened by pollution and possession. The river is found to be Dhaka's main outlet of sewage waste. There have been reports that the river is being polluted by discharge of industrial effluents, municipal wastewaters, household wastes, clinical and pathological wastes, oils and human excreta (Kamal et al. 1999). The largest share of pollution load into the river Buriganga appears to be from about 200 tannery industries in the Hazaribagh and Rayerbazar area. Studies show that up to $15,000 \mathrm{~m}^{3}$ of liquid wastes, $19,000 \mathrm{~kg}$ of solid wastes and $17,600 \mathrm{~kg}$ of Biological Oxygen Demand (BOD) load goes into the Buriganga each day from the industries (Faisal et al. 2001).

Since the bacteria are well known agents of mineralization and transformation of organic and inorganic matters in aquatic ecosystem. Therefore, the objectives of the present study were: (i) isolation of indigenous bacterial isolates possessing high metabolic activities, and (ii) stimulation of inorganic nutrient regeneration by adding those bacteria.

*Author for correspondence: <makarim10@yahoo.com>. 
For the isolation of effective bacterium that might be active at high temperature, surface water samples $(5 \mathrm{~cm}$ depth) were collected from the river Buriganga using $2 \mathrm{~L}$ plastic bottles during summer when temperature was about $32^{\circ} \mathrm{C}$ and were carried to the laboratory within an hour of sampling. The temperature, Dissolved Oxygen (DO), pH, Total Dissolved Solids (TDS) of the collected water samples were measured using standard kits.

From 110 fast growing bacterial isolates, 36 were selected considering growth pattern and colony morphology and finally BW-2 was selected for its biotechnological application.

Table 1 Morphological, physiological and biochemical characteristics of bacterial isolate BW-2

\begin{tabular}{|c|c|c|c|c|c|c|}
\hline \multicolumn{2}{|c|}{ Characteristics } & Results & \multicolumn{2}{|c|}{ Characteristics } & Results & $\begin{array}{c}\text { Provisional } \\
\text { Identification }\end{array}$ \\
\hline \multicolumn{2}{|c|}{ Gram reaction } & - & \multicolumn{2}{|l|}{$\mathrm{KOH}$} & + & \\
\hline \multicolumn{2}{|c|}{ Cell shape } & $\begin{array}{l}\text { Short rod, } \\
\text { occur singly }\end{array}$ & \multicolumn{2}{|c|}{ Utilization of citrate } & - & Xanthomonas \\
\hline \multicolumn{2}{|l|}{ Spore } & $\begin{array}{l}\text { Non spore } \\
\text { former }\end{array}$ & \multicolumn{2}{|c|}{ Utilization of propionate } & - & sp. \\
\hline \multicolumn{2}{|l|}{ Catalase } & + & \multicolumn{2}{|c|}{ Indole formation } & - & \\
\hline \multicolumn{2}{|l|}{ Oxidase } & + & \multicolumn{2}{|c|}{$\begin{array}{l}\text { Dihydroxy } \\
\text { production }\end{array}$} & - & \\
\hline \multicolumn{2}{|l|}{ VP } & - & $\begin{array}{l}\text { Fermen } \\
\text { tation }\end{array}$ & $\begin{array}{l}\text { D-glucose (no } \\
\text { gas) }\end{array}$ & - & \\
\hline \multicolumn{2}{|l|}{ MR } & - & & L-arabinose & - & \\
\hline \multicolumn{2}{|l|}{ Levan } & - & & D-xylose & - & \\
\hline \multicolumn{2}{|c|}{$\begin{array}{l}\text { Phenayal alanine } \\
\text { deaminase }\end{array}$} & - & & D-mannitol & - & \\
\hline \multicolumn{2}{|c|}{ Protease } & + & \multicolumn{2}{|c|}{ Degradation of tyrosine } & + & \\
\hline \multicolumn{2}{|c|}{ Deep glucose agar } & Aerobic & \multicolumn{2}{|c|}{ Degradation of urea } & + & \\
\hline \multicolumn{2}{|c|}{ Motility } & - & \multicolumn{2}{|c|}{ Nitrate reduction } & - & \\
\hline \multirow[t]{3}{*}{ Hydrolysis } & Starch & + & \multirow{2}{*}{\multicolumn{2}{|c|}{$\begin{array}{l}\text { Egg yolk lecithinase } \\
\text { Egg yolk lipase }\end{array}$}} & - & \\
\hline & Casein & + & & & - & \\
\hline & Gelatin & + & & & & \\
\hline
\end{tabular}

"+" indicate positive and "-" indicate negative

Bacterial inocula were prepared following method described by Karim et al. 2013. Five $\mathrm{ml}$ of bacterial cells re-suspension was used as inoculum and it was added into the treatment bottles. Bacterial activities were evaluated by the changes of inorganic nutrient regeneration into the water during incubation with or without adding bacteria. Just after adding bacteria into the experimental glass bottles, two glass bottles (in duplicate) were taken for chemical analysis without any disturbance of the system and considered as 0-day. The experiments were continued up to 15 days with 5 days interval. For chemical analysis, water samples were passed through the filter paper (Whatman No. 42, England) to eliminate suspended solid particles. The concentrations of inorganic form of nitrogen (DIN: ammonium, nitrate and nitrite) and phosphorus (DIP) in control and experimental glass bottles were measured following methods 
described by Karim et al. 2013. Important physiological and biochemical characteristics were studied for the identification of the selected isolate (Sneath et al. 1986, SAB 1957 and Claus 1995).

The morphological, physiological and biochemical characteristics of the bacterial isolate Xanthomonas sp. are presented in Table 1. The isolate BW-2 exhibited remarkably high growth rates between $30^{\circ} \mathrm{C}$ and $40^{\circ} \mathrm{C}$ but didn't grow well at relatively low $\left(10^{\circ} \mathrm{C}\right)$ and high temperature $\left(55^{\circ} \mathrm{C}\right)$ and was considered to be mesophilic (Fig. 1). In regards to proteolytic activities, BW-2 possessed high activities by clear zone into the medium and increased with incubation period (Fig. 2).

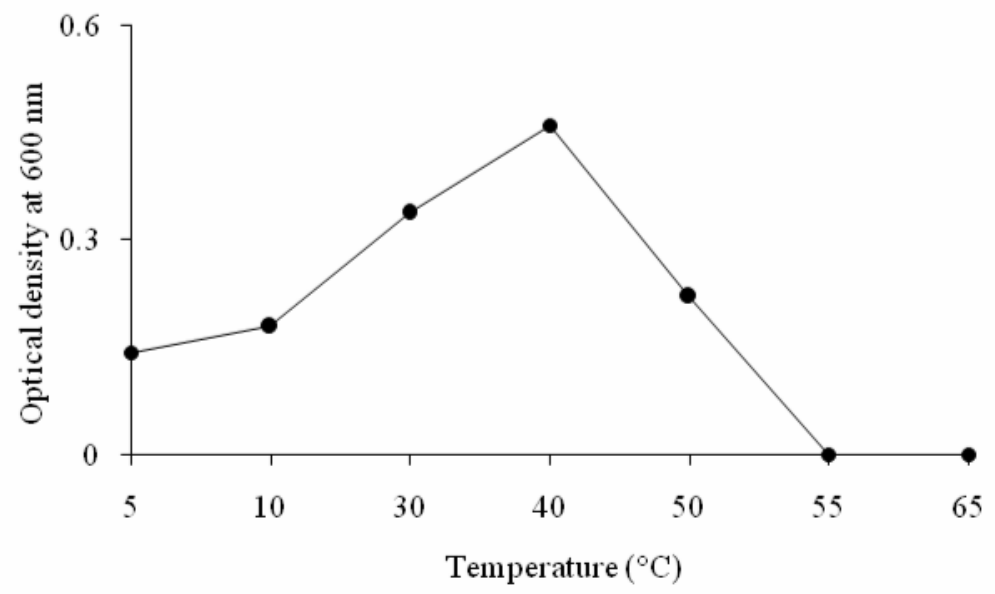

Fig. 1 Growth of BW-2 bacterial isolate at different temperatures.

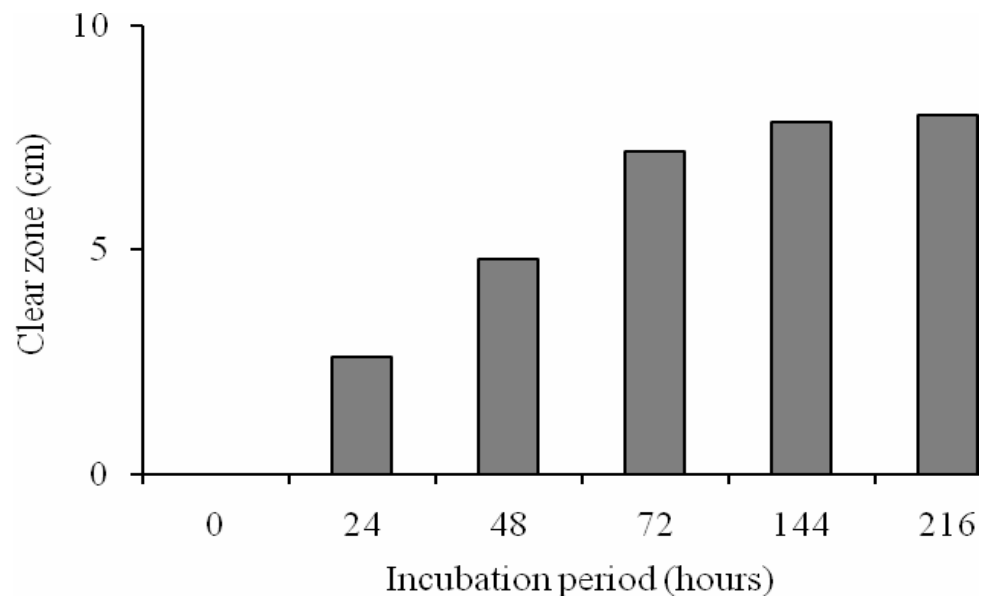

Fig. 2 Proteolytic activity of the bacterial isolate (BW-2) at different hours of incubation at $37^{\circ} \mathrm{C}$. 
The initial concentration of DIP in control was $0.06 \mathrm{mg} / 1$, while in the system of adding Xanthomonas sp. it increased to $0.29 \mathrm{mg} / 1$ (Fig. 4). Net releases of DIP were $0.13 \mathrm{mg} / 1$ in control and $0.23 \mathrm{mg} / 1$ after adding Xanthomonas sp., while, net releases of DIN were $2.52 \mathrm{mg} / 1$ in control and $5.18 \mathrm{mg} / 1$ after adding Xanthomonas sp. (Fig. 3).
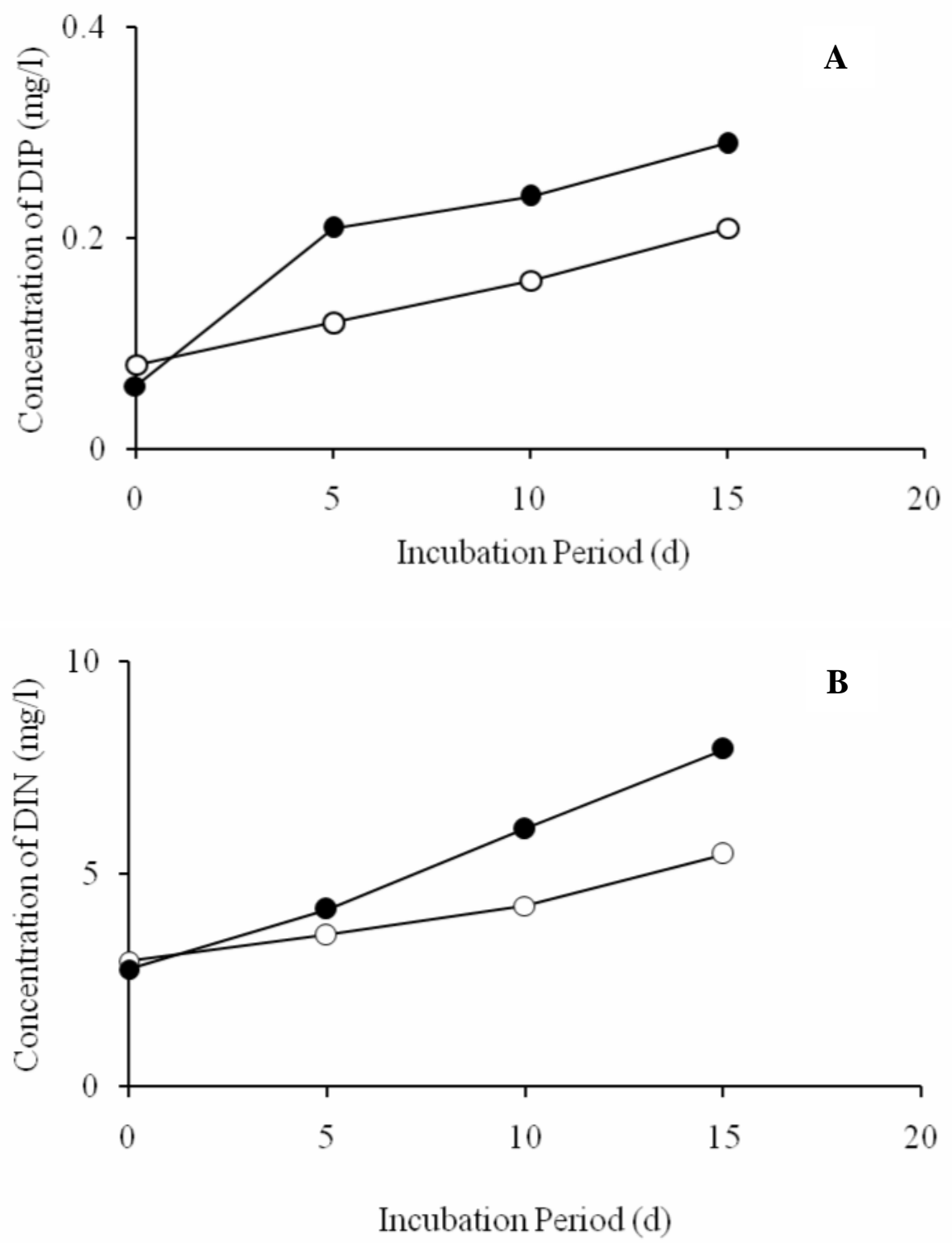

Fig. 3 Effect of Xanthomonas sp. on the change of dissolved inorganic phosphorus (A) and nitrogen (B) after different days of incubation period. Without Xanthomonas sp. (o) and with Xanthomonas sp. $(\bullet)$. 
After adding Xanthomonas sp., net amounts of DIN and DIP regeneration in water were markedly enhanced and about two folds higher than the control counterpart. So, result of the experiment conducted with Xanthomonas sp. and incubated at in situ temperature showed that Xanthomonas sp. could be effective at high temperature. Further study at the next stage regarding the removal of enhanced inorganic nutrients from the water is recommended.

\section{LITERATURE CITED}

BIAMON, E.J. and HAJEN, T.C. 1983. Survival and distribution of Aeromanas hydrophila in nearshore coastal waters of Puerto Rico receiving rum distillery effluent. Water Res. 17: 319-326.

CLAUS, G.W. 1995. Understanding microbes. (4th Ed.). W.H. Freeman and Company, New York. pp. 547.

FAISAL, I.M., SHAMIN, R. and JUNAID, J. 2001. Industrial pollution, In: Nishat, A., Ullah, M. and Haque, A.K.E. (eds). Bangladesh Environment Outlook-2001. Centre for Sustainable Development (CFSD), Dhaka.

KAMAL, M.M., MALMGREN-HANSEN, A. and BADRUZZAMAN, A.B.M. 1999. Assessment of pollution of the river Buriganga, Bangladesh, using a water quality model. Water. Sci. Technol. 40(2): 12936.

KARIM, M.A., NAZNEEN, A. and HOQUE, S. 2013. Heterotrophic activities in eutrophic lake sediment by indigenous bacterium Bacillus firmus. Bangladesh J. Zool. 41(1): 73-78.

MATCHES, J.R., LISTON, J. and CURRAN, D. 1974. Clostridium perfringens in the environment. Appl. Microbiol. 28: 655-660.

SAB (Society of American Bacteriologists). 1957. Manual of microbiological methods. McGraw-Hill Book Co. Inc. NY. pp. 1-315.

SNEATH, P.H.A., MAIR, N.S., SHARPE, M.E. and HOLT, J.G. (Eds.). 1986. Bergey's manual of systematic bacteriology. Vol. 2. The Williams and Wilkins Co., Baltimore, USA. pp. 965-1594. 